\title{
Hope or Hype: Beta-Blockers in Traumatic Brain Injury
}

\author{
Luis Rafael Moscote-Salazar ${ }^{1,2}$ Tariq Janjua ${ }^{3}$ William A Florez-Perdomo ${ }^{4, \odot ~ H a r o l d ~ V a s q u e z ~}{ }^{4,5}$
}

1Paracelsus Medical University, Salzburg, Austria

2Department of Neurosurgery, Center of Biomedical Research, University of Cartagena, Cartagena de Indias, Colombia

${ }^{3}$ Neurocritical Care Unit, Regions Hospital, Saint Paul, Minnesota, United States

${ }^{4}$ Latinamerican Council of Neurocritical Care, Colombia

${ }^{5}$ Department of Medicine, Universidad del Sinu, Cartagena, Colombia

Indian ] Neurotrauma:2021;18:98

Traumatic brain injury (TBI) has significant consequences for patients, families, and healthcare systems worldwide. ${ }^{1}$ The mortality remains considerably high despite modern advances in critical management. After the primary event of TBI, the structural lesion in the brain parenchyma triggers complex pathophysiological processes. One of the identified mechanisms is associated with the release of systemic catecholamines, producing a hyperadrenergic state with high-utility of glucose and oxygen. ${ }^{2}$ This hyperadrenergic state has been linked to increased mortality, with the possibility that if we modulate catecholamine levels, we can positively impact the outcome.

Modulation of the hyperadrenergic state, based on physiological and pharmacological concepts, can be done using pharmacological interventions in the form of $\beta$-blockers. ${ }^{3}$ Beta-blockers belong to a family of drugs with the ability to bind to $\beta$-adrenergic receptors, using a competitive antagonism mechanism. The use of these drugs has been extensive in cardiac pathologies such as ischemic heart disease where they reduce cardiac oxygen consumption, heart rate, and contractility.

Alali et al, in a systematic review with a low-quality of evidence, demonstrated a favorable effect of $\beta$-blockers on mortality in patients with TBI. ${ }^{4}$ In a prospective, observational cohort study by the American Association for the Surgery of Trauma Clinical Trial Group in patients with TBI who received $\beta$-blockers, there was improvement in patient survival. ${ }^{5}$ Arbabi et al reported that the administration of any $\beta$-blocker is associated with a better prognosis in trauma patients. ${ }^{6}$

Which $\beta$ blocker to administer in TBI? Nonselective or selective $\beta-1$ receptor antagonist? Although it seems that any agent with a $\beta$-blocker effect could be administered,

\author{
Address for correspondence Luis Rafael Moscote-Salazar, \\ MD, Department of Neurosurgery, University of Cartagena, \\ Cra. 50 \#24120, Cartagena de Indias 130014, Colombia \\ (e-mail: rafaelmoscote21@gmail.com).
}

its different pharmacological profiles will require a rational study to determine effectiveness in the context of TBI, including route of administration.

Finally, we consider that the potential effects on outcome in patients with TBI should be confirmed in well-designed and robust studies. The implementation of a pharmacological and economic strategy such as $\beta$-blockers can be a hope for the management of this catastrophic disease.

\section{Funding}

None.

\section{Conflict of Interest}

None declared.

\section{References}

1 Iaccarino C, Carretta A, Nicolosi F, Morselli C. Epidemiology of severe traumatic brain injury. J Neurosurg Sci 2018;62(5): 535-541

2 Tran TY, Dunne IE, German JW. Beta blockers exposure and traumatic brain injury: a literature review. Neurosurg Focus 2008;25(4):E8

3 Ram CV. Beta-blockers in hypertension. Am J Cardiol 2010; 106(12):1819-1825

4 Alali AS, Mukherjee K, McCredie VA, et al. Beta-blockers and traumatic brain injury: a systematic review, meta-analysis, and Eastern Association for the Surgery of Trauma Guideline. Ann Surg 2017;266(6):952-961

5 Ley EJ, Leonard SD, Barmparas G, et al; Beta Blockers TBI Study Group Collaborators. Beta blockers in critically ill patients with traumatic brain injury: Results from a multicenter, prospective, observational American Association for the Surgery of Trauma study. J Trauma Acute Care Surg 2018;84(2):234-244

6 Arbabi S, Campion EM, Hemmila MR, et al. Beta-blocker use is associated with improved outcomes in adult trauma patients. J Trauma 2007;62(1):56-61, discussion 61-62 published online

September 29, 2020
DOI https://doi.org/

10.1055/s-0040-1717212

ISSN 0973-0508.
(C)2020. Neurotrauma Society of India.

This is an open access article published by Thieme under the terms of the Creative Commons Attribution-NonDerivative-NonCommercial-License, permitting copying and reproduction so long as the original work is given appropriate credit. Contents may not be used for commercial purposes, or adapted, remixed, transformed or built upon. (https://creativecommons.org/licenses/by-nc-nd/4.0/).

Thieme Medical and Scientific Publishers Pvt. Ltd. A-12, 2nd Floor, Sector 2, Noida-201301 UP, India 